\title{
Study in the Quality of Clinical Documentation Practice in Chitwan Medical College Teaching Hospital, Nepal
}

\author{
Pandit U
}

\begin{abstract}
Background: Primary documentation of a patient is crucial for making effective healthcare decision and improvements in the quality of care. The objective of this study was to assess the quality of current documentation practice in tertiary care hospitals. Materials and methods: This was an assessment of medical documentation practice of one year from the period of January 2010 to December 2010 in Chitwan Medical College, Teaching Hospital. Total 184 patients' discharge files were enrolled and reviewed. Documentation was reviewed in its quality such as completeness, Coherent, consistency and Legibility. Results: In overall pooled analysis, High omission rate was observed in final diagnosis, results (cure, improved, referral and death), hospital stay, and final case summary. Although, satisfactory performance was observed in complete set of forms (72.2\%); Patient consent for treatment \&release authorization forms (78.2\%) and treatment chart (60.8\%), the overall pooled performance in ten components showed50\% performance gap. Study demonstrated that documentation and its legibility, coherent and consistency in all departments needs substantial improvements in the institution.
\end{abstract}

Key words: Audit, documentation, quality care

\section{INTRODUCTION}

Quality assurance in the institution depends upon the availability of accurate data. In health institution, the documentation of a patient is therefore a fundamental skill that underpins high quality patient care ${ }^{1}$. Previous studies regarding quality assurance showed that the adverse incidence rate is higher in those institutions where there is missing of records. Primary documentation of a patient not only for making rapport but also to produce research in clinical case management, future plan for improvement in quality, upgrading the technology, collective reporting to higher authority and for some other medico legal importance. However it is not always given the priority it deserves.

There are many problems with the documentation systems which are uncovered in most of the health institutions. The problems are like missing the data, incorrect data, and duplication of patient's record and unreadable entries. These poor quality records meant that they could not be used as reliable sources of information for quality improvement efforts. Such an unreliable data should not be used in making decisions in healthcare management. The lack of correct and timely entry data can lead to poor choices in clinical practice, medication errors, inappropriate repeating of tests, unnecessary referrals, and the waste of time and other resources. So, it is imperative

Address for correspondence:

Dr. Upendra Pandit

Department of Obstetrics \& Gynecology

Nepalgunj Medical College Teaching Hospital

Nepagunj, Banke, Nepal

E-mail: drupandit@gmail.com that all health professionals including nurses and midwives should understand the significance of the contents of the patient's medical records. They should know the potentiality of these documents which can be used in health care planning and quality health care management. Most important finding in previous study pointed that poor quality of the information present in patient records was associated with higher rates of adverse events, implying that the quality of the present patient information is a predictor of the quality of care ${ }^{3-5}$. Moreover, the communication and information deficit was also observed in previous study especially in areas such as medication reconciliation, pending test results, and adequate follow-up plans ${ }^{6}$. That is why, institution of rigorous measurement, feedback, and multidisciplinary, multimodal quality improvement processes improved the inclusion of data elements in discharge documentation which is required for effective health care system.

Chitwan School of Medical Sciences, Teaching hospitals 360 bedded teaching hospital. The annual admissions rate in the year 2010 were 14356. The numbers of cases admitted in Medicine were 3865(26.9\%), Paediatrics 1991(13.8\%), Psychiatric 496(3.4\%), Emergency 3947(27.4\%), Surgery 1662(11.5\%), Orthopaedics 769(5.3\%), Gynecology and obstetrics $1259(8.7 \%)$ and ENT head and neck surgery $367(2.5 \%)$ respectively. Institute started using electronic discharge system from the mid of 2010. The electronically stored patients information like blood results, imaging results and discharge summaries are available to view by all authorized parties anywhere in the hospital.

Duty staff of respective departments fills all the allocated forms during the admission. Primary information like identification of 
a patient is filled up by nursing staff in admission form, nursing observation form, vital sign chart and Input and output chart. The detail information about diseases like history, examination findings, investigation report, treatment order, operation notes (in surgery), daily follow up notes and discharge summary are completed by duty doctor (house officer).

Prior to discharging the patient from hospital, a discharge summary (this to be hand written or electronic) is required to be completed by the doctor. Copies of patients' record are kept in medical record department.

This study intended to review the current documentation practice in its three components in Chitwan School of Medical Sciences. The first component was its structure which includes the organizational support for the system: staffing, physical space, forms, Technology and materials and standardization. Second component was its procedure which included methods of documentation, retrieving, filing/coding and third component was the quality of the documentation like its coherence and consistency as well as clarity.

\section{MATERIALS AND METHOD}

We have performed a retrospective patient record review study in a random sample of 184 patient documentation file in Chitwan Medical Collage Teaching hospital. From each department, we randomly selected admissions file of those patient who were stayed More than 24 hours in hospital from
January 2010 to December 2010. The patient records of the sampled admissions were reviewed by a trained team of 3 medical practitioners with a structured record-review process. In the first stage of the review process, Discharge file of all department (Medicine, Pediatrics, Psychiatric, Emergency medicine, Surgery, Orthopedic, Gynecology and ENT/head \& neck surgery) from January 2010 to December 2010 were randomly extracted. Patient record file were obtained from record section.

Files were reviewed by physicians in the second stage of the review process. Based on a standardized procedure according to the indicators and its definition, reviewers determined the presence or absence of documentation. All quantitative and qualitative data were entered and analysed using Microsoft Excel. Proportions of all indicators were calculated and reported.

\section{Guidelines}

In this study the measurement of the current documentation practice was performed with respect to the data of ten components and its quality indicators according to its definitions ${ }^{6,7}$. Only three component indicators like discharge summary, legible and coherent and consistency were applied to study patient's files of the emergency department.

Components, Indicators and definition of the Quality of Medical Documentation (Adapted ${ }^{6.7}$ )

\begin{tabular}{|l|l|l|}
\hline Component & Indicator & Definition \\
\hline 1. Complete set of forms on chart & $\begin{array}{l}\text { Number of complete medical } \\
\text { records in sample, divided by total } \\
\text { sample size }\end{array}$ & $\begin{array}{l}\text { The total number of medical records in the } \\
\text { sample with all the forms required at } \\
\text { final admission. }\end{array}$ \\
\hline $\begin{array}{l}\text { 2.Complete admission and discharge } \\
\text { records }\end{array}$ & $\begin{array}{l}\text { No of completed admission records in } \\
\text { the form divided by total sample size }\end{array}$ & $\begin{array}{l}\text { The total no of medical records in the } \\
\text { sample that have the admission form } \\
\text { completed, including In-patient no, name, } \\
\text { age and sex, address, provisional } \\
\text { diagnosis, final diagnosis, procedure(if } \\
\text { applicable), hospital days, date of } \\
\text { admission and discharge, result, final case } \\
\text { summary. }\end{array}$ \\
\hline $\begin{array}{l}\text { 3.Complete discharge summary } \\
\text { records }\end{array}$ & $\begin{array}{l}\text { No of completed discharge summary } \\
\text { records divided by total sample size. }\end{array}$ & $\begin{array}{l}\text { The total no of medical records in the } \\
\text { sample that have the discharge summary } \\
\text { form completed, including In-patient no, } \\
\text { name, age and sex, address, name of } \\
\text { consultant, date of admission and } \\
\text { discharge, final diagnosis, case summary } \\
\text { (history, clinical findings), investigations } \\
\text { records, operative procedure and findings } \\
\text { (if applicable), histopathology report(if } \\
\text { applicable), treatment during hospital } \\
\text { stay, condition at the time of discharge, } \\
\text { special note, advice on discharge and } \\
\text { authorized signature. }\end{array}$ \\
\hline \hline
\end{tabular}




\begin{tabular}{|c|c|c|}
\hline Component & Indicator & Definition \\
\hline $\begin{array}{l}\text { 4. Patient consent for treatment and } \\
\text { release authorization forms }\end{array}$ & $\begin{array}{l}\text { No of medical records in samples } \\
\text { with a signature on the authorization } \\
\text { forms sample divided by total sample } \\
\text { size. }\end{array}$ & $\begin{array}{l}\text { The total no of medical records in the } \\
\text { sample that had patient signature / finger } \\
\text { print on the authorization forms. }\end{array}$ \\
\hline 5. Vital sign chart & $\begin{array}{l}\text { No of medical records in the sample } \\
\text { with complete graphical presentation } \\
\text { divided by sample size. }\end{array}$ & $\begin{array}{l}\text { The total no of medical records in the } \\
\text { sample with that complete includes } \\
\text { graphical presentation and patient } \\
\text { identification record. }\end{array}$ \\
\hline 6. Nurses Observation & $\begin{array}{l}\text { No of medical records in the sample } \\
\text { with complete intake output chart } \\
\text { divided by sample.. }\end{array}$ & $\begin{array}{l}\text { The total no of medical records in the } \\
\text { sample with complete including } \\
\text { Temperature, pulse, respiration, blood } \\
\text { pressure, observation record including } \\
\text { patient identification. }\end{array}$ \\
\hline 7. Intake and Output chart & $\begin{array}{l}\text { No of medical records in the sample } \\
\text { with complete intake output chart } \\
\text { divided by samples. }\end{array}$ & $\begin{array}{l}\text { Total no of medical records in the sample } \\
\text { with complete including date, time, } \\
\text { IV infusion, oral,, urine, aspiration, } \\
\text { drainage vomitus and colour. }\end{array}$ \\
\hline 8. Treatment chart & $\begin{array}{l}\text { No of medical records in the sample } \\
\text { with complete treatment chart divided } \\
\text { by samples. }\end{array}$ & $\begin{array}{l}\text { The total no of medical records in the } \\
\text { sample complete treatment chart includes } \\
\text { patient identification( name age ward IP } \\
\text { no, bed no), date, drugs in block letter, } \\
\text { dose, route, doctor signature, } \\
\text { discontinuation date. }\end{array}$ \\
\hline 9. Legible & $\begin{array}{l}\text { No of medical records in the sample } \\
\text { with legible medical notations with } \\
\text { respect to the indication, diagnosis } \\
\text { and progress note divided by samples. }\end{array}$ & $\begin{array}{l}\text { The total no of medical records in the } \\
\text { sample with complete legible medical } \\
\text { notations with respect to the indications } \\
\text { diagnosis and progress notes. Legible } \\
\text { documentation was defined as writing that } \\
\text { can be clearly understood on forms with } \\
\text { respect to the name of the patient, } \\
\text { inpatient no, diagnosis, ICD coding } \\
\text { medical/surgical indications and progress } \\
\text { note. }\end{array}$ \\
\hline 10. Coherent and consistent & $\begin{array}{l}\text { No of medical records in the sample } \\
\text { that were coherent and consistent in } \\
\text { content divided by samples. }\end{array}$ & $\begin{array}{l}\text { The total no of medical records in the } \\
\text { sample that contained entries that } \\
\text { were coherent and consistent with i.e they } \\
\text { coincided with the diagnosis, indication } \\
\text { and treatment during admission, discharge } \\
\text { and ward follow up according to available } \\
\text { protocol and that were in chronological } \\
\text { sequence and related to the progress } \\
\text { notes. }\end{array}$ \\
\hline
\end{tabular}




\section{RESULTS AND OBSERVATIONS}

Among 184 samples files from eight departments, three of them were without discharge summary. Three of ten components indicators showed only satisfactory score of the documentation practice. Component Indicators with high score performance were complete set of forms, Patient consent for treatment and release authorization forms and treatment chart. The current performances of these three indicators ranged from 60.8 to 78.2 percent. The seven indicators showed small variation in the performances scores of the departments ranged from 30.4 to 58.1 percent among the eight.

Table I summarizes the performance of eight departments in ten quality indicators. Table II summarizes the performance gap among the eight departments. The performance gaps of the inter departments were ranged from 20 to 90 percent. Overall performance gap was observed 50 percent in ten indicators in eight departments.

\begin{tabular}{|c|c|c|c|c|c|c|c|c|c|}
\hline \multirow{2}{*}{$\begin{array}{l}\text { Component/Quality } \\
\text { Indicators }\end{array}$} & \multicolumn{9}{|c|}{ Departments and percentage } \\
\hline & $\begin{array}{c}\text { Med. } \\
\text { No. } \\
(\%)\end{array}$ & $\begin{array}{l}\text { Pae. } \\
\text { No. } \\
\text { (\%) }\end{array}$ & $\begin{array}{l}\text { Psy. } \\
\text { No. } \\
\text { (\%) }\end{array}$ & $\begin{array}{c}\text { Emer. } \\
\text { No. } \\
(\%)\end{array}$ & $\begin{array}{l}\text { Sur. } \\
\text { No. } \\
(\%)\end{array}$ & $\begin{array}{l}\text { Ortho. } \\
\text { No. } \\
\text { (\%) }\end{array}$ & $\begin{array}{l}\text { OBG. } \\
\text { No. } \\
(\%)\end{array}$ & $\begin{array}{l}\text { ENT } \\
\text { No. } \\
(\%)\end{array}$ & $\begin{array}{l}\text { Pooled } \\
\text { No. } \\
(\%)\end{array}$ \\
\hline Sample Size & 24 & 23 & 24 & 22 & 24 & 22 & 23 & 22 & 184 \\
\hline Complete Set of forms & $\begin{array}{c}20 \\
(80)\end{array}$ & $\begin{array}{c}21 \\
(91)\end{array}$ & $\begin{array}{c}13 \\
(54)\end{array}$ & - & $\begin{array}{c}18 \\
(75)\end{array}$ & $\begin{array}{c}18 \\
(81)\end{array}$ & $\begin{array}{l}22 \\
(95)\end{array}$ & $\begin{array}{c}21 \\
(91)\end{array}$ & $\begin{array}{c}133 \\
(72.2)\end{array}$ \\
\hline $\begin{array}{l}\text { Complete record in } \\
\text { admission and discharge } \\
\text { form }\end{array}$ & $\begin{array}{l}10 \\
(41)\end{array}$ & $\begin{array}{c}4 \\
(17)\end{array}$ & $\begin{array}{c}3 \\
(12)\end{array}$ & - & $\begin{array}{c}12 \\
(52)\end{array}$ & $\begin{array}{c}8 \\
(36)\end{array}$ & $\begin{array}{l}17 \\
(73)\end{array}$ & $\begin{array}{c}19 \\
(86)\end{array}$ & $\begin{array}{c}73 \\
(39.6)\end{array}$ \\
\hline $\begin{array}{l}\text { Complete record in } \\
\text { discharge summary }\end{array}$ & $\begin{array}{c}99 \\
(37)\end{array}$ & $\begin{array}{c}14 \\
(66)\end{array}$ & $\begin{array}{c}5 \\
(22)\end{array}$ & $\begin{array}{c}6 \\
(27)\end{array}$ & $\begin{array}{c}7 \\
(30)\end{array}$ & $\begin{array}{c}15 \\
(68)\end{array}$ & $\begin{array}{l}17 \\
(73)\end{array}$ & $\begin{array}{c}14 \\
(66)\end{array}$ & $\begin{array}{c}87 \\
(47.2)\end{array}$ \\
\hline $\begin{array}{l}\text { Patient consent for } \\
\text { treatment and release } \\
\text { authorization forms }\end{array}$ & $\begin{array}{c}22 \\
(91)\end{array}$ & $\begin{array}{c}21 \\
(91)\end{array}$ & $\begin{array}{c}22 \\
(91)\end{array}$ & - & $\begin{array}{l}18 \\
(75)\end{array}$ & $\begin{array}{c}20 \\
(90)\end{array}$ & $\begin{array}{c}20 \\
(86)\end{array}$ & $\begin{array}{c}21 \\
(91)\end{array}$ & $\begin{array}{c}144 \\
(78.2)\end{array}$ \\
\hline Vital sign chart record & $\begin{array}{c}14 \\
(63)\end{array}$ & $\begin{array}{c}21 \\
(91)\end{array}$ & $\begin{array}{c}8 \\
(34)\end{array}$ & - & $\begin{array}{c}21 \\
(87)\end{array}$ & $\begin{array}{c}14 \\
(66)\end{array}$ & $\begin{array}{c}22 \\
(95)\end{array}$ & $\begin{array}{c}7 \\
(31)\end{array}$ & $\begin{array}{c}107 \\
(58.1)\end{array}$ \\
\hline $\begin{array}{l}\text { Nurses Observation chart } \\
\text { record }\end{array}$ & $\begin{array}{c}6 \\
(25)\end{array}$ & $\begin{array}{c}15 \\
(65)\end{array}$ & $\begin{array}{c}13 \\
(59)\end{array}$ & - & $\begin{array}{c}6 \\
(25)\end{array}$ & $\begin{array}{c}7 \\
(31)\end{array}$ & $\begin{array}{c}21 \\
(91)\end{array}$ & $\begin{array}{c}20 \\
(90)\end{array}$ & $\begin{array}{c}88 \\
(47.8)\end{array}$ \\
\hline $\begin{array}{l}\text { Intake and Output chart } \\
\text { record }\end{array}$ & $\begin{array}{c}7 \\
(31)\end{array}$ & $\begin{array}{c}4 \\
(17)\end{array}$ & $\begin{array}{c}3 \\
(21)\end{array}$ & - & $\begin{array}{c}10 \\
(50)\end{array}$ & $\begin{array}{c}4 \\
(21)\end{array}$ & $\begin{array}{c}8 \\
(34)\end{array}$ & $\begin{array}{c}20 \\
(90)\end{array}$ & $\begin{array}{c}56 \\
(30.4)\end{array}$ \\
\hline Treatment chart record & $\begin{array}{c}9 \\
(57) \\
\end{array}$ & $\begin{array}{c}19 \\
(82)\end{array}$ & $\begin{array}{c}15 \\
(68) \\
\end{array}$ & - & $\begin{array}{c}12 \\
(50)\end{array}$ & $\begin{array}{r}18 \\
(81)\end{array}$ & $\begin{array}{c}20 \\
(86)\end{array}$ & $\begin{array}{c}19 \\
(91)\end{array}$ & $\begin{array}{c}112 \\
(60.8) \\
\end{array}$ \\
\hline Legible (clarity) & $\begin{array}{c}10 \\
(41)\end{array}$ & $\begin{array}{c}7 \\
(30) \\
\end{array}$ & $\begin{array}{c}4 \\
(16) \\
\end{array}$ & $\begin{array}{c}4 \\
(18) \\
\end{array}$ & $\begin{array}{c}7 \\
(29) \\
\end{array}$ & $\begin{array}{c}7 \\
(29) \\
\end{array}$ & $\begin{array}{c}7 \\
(29) \\
\end{array}$ & $\begin{array}{c}12 \\
(54) \\
\end{array}$ & $\begin{array}{c}58 \\
(31.5) \\
\end{array}$ \\
\hline $\begin{array}{l}\text { Coherent and consistency } \\
\text { of recording }\end{array}$ & $\begin{array}{c}12 \\
(50)\end{array}$ & $\begin{array}{c}7 \\
(30.4)\end{array}$ & $\begin{array}{c}4 \\
(16.6)\end{array}$ & $\begin{array}{c}6 \\
(27)\end{array}$ & $\begin{array}{c}8 \\
(33.3) \\
\end{array}$ & $\begin{array}{c}8 \\
(36.3)\end{array}$ & $\begin{array}{c}10 \\
(43.4)\end{array}$ & $\begin{array}{c}8 \\
(36.3)\end{array}$ & $\begin{array}{c}61 \\
(34.2)\end{array}$ \\
\hline Total & $\begin{array}{c}125 \\
(52.0)\end{array}$ & $\begin{array}{c}133 \\
(57.8)\end{array}$ & $\begin{array}{c}90 \\
(37.5)\end{array}$ & $\begin{array}{c}16 \\
(72)\end{array}$ & $\begin{array}{l}122 \\
(50)\end{array}$ & $\begin{array}{l}119 \\
(54)\end{array}$ & $\begin{array}{l}164 \\
(71)\end{array}$ & $\begin{array}{c}161 \\
(73.1)\end{array}$ & $\begin{array}{l}930 \\
(50)\end{array}$ \\
\hline
\end{tabular}

Med. = Medicine, Pae. $=$ Pediatrics, Psy. = Psychiatry, Emer. = Emergency,

Sur. = Surgery, Ortho. = Orthopedics, OBG. = Obstetrics \& Gynaecology

Table I: Number and Percentage of medical records meeting quality standards 


\begin{tabular}{|l|c|c|c|c|c|c|c|}
\hline Component/Indicator & Med. & Pae. & Psy. & Sur. & Ortho. & OBG & ENT \\
\hline Complete admission record & 0.6 & 0.9 & 0.9 & 0.5 & 0.7 & 0.3 & 0.2 \\
\hline Complete discharge summary & 0.7 & 0.4 & 0.4 & 0.7 & 0.4 & 0.3 & 0.4 \\
\hline $\begin{array}{l}\text { Nursing management(Vitals, } \\
\text { Nursing Observation, I/O Chart) }\end{array}$ & 0.7 & 0.5 & 0.8 & 0.5 & 0.7 & 0.3 & 0.3 \\
\hline Legible & 0.6 & 0.7 & 0.9 & 0.8 & 0.8 & 0.8 & 0.5 \\
\hline Coherent and consistent & 0.5 & 0.7 & 0.8 & 0.7 & 0.6 & 0.6 & 0.6 \\
\hline
\end{tabular}

Note: "Performance gap" is defined as the proportion of all records in the samples that do not meet a particular standard. For example performance gap 0.5 indicates 50 percent gap need to be eliminated.

Table II: Performance gap to meet each standard

\section{DISCUSSION}

The quality of the recorded information in patient records seems to be a predictor of the quality of care. Better registration of patient information could contribute to better patient outcomes and safer healthcare. Documentation in medical records is poorly designed that is why it is difficult to maintain. This deficiency also obtained in this study. Writing case summary in admission form during the time of discharge is wrongly instructed as there is separate from available for writing discharge summary. It should be indicate that case summary should be written at the time of admission not at the time of discharge.

Deficiencies in discharge summary were commonly found in most of the hospital. A review from American Medical Association, found that important data often were missing from discharge summaries. In the review of 73 studies, the primary diagnosis was omitted a median of 17.5 percent of the time, a list of medications at discharge did not appear in $21 \%$ of summaries, and pending test result were not included in $65 \%$. In this study there were similar results as afore mentions findings. So lack of standard documentation was observed in admission and discharge form. High omission rate was observed in final diagnosis, result (cure, improved, referral and death), hospital stay, and final case summary. Missing patient record components and poor records of the available patient information probably reflect different underlying problems in hospital. The first suggesting administrative and process issues is the inability to use of available An electronic discharge summary more easily create hospital discharge summaries but there was no difference in primary care physicians satisfaction ${ }^{9-}$ ${ }^{10}$. The training in electronic format is necessary to crate prompt and accurate documentation in admission and discharge summary.

During admission the presenting symptoms, main clinical findings, investigation finding, treatment protocol/ guideline should be recorded. However, redesigning of the admission form is recommended. Hopefully final corrected form for the admission will prevent the high omission rate. High omission rate was also observed particularly the subjects like blood transfusion record in anemic case, Blood Pressure record for hypertensive case, blood sugar level for diabetic patient at day of discharge. Likewise electrolyte and blood count (platelets) etc. Records of inter departmental consultation, use of standardized medical abbreviations, whether case was admitted from emergency/ OPD, operative findings, Status during hospital admission/stay (any complication observed), time of follow up were frequently omitted in discharge summary. There is relatively high omission rate of the patients discharge condition. Ideally such information allows the sub acute care team to understand the patients health and functional status at the time of hospital discharge, enabling the team to better identify the worrisome about discharged patient. They otherwise do not know well. Lack of accuracy and continuity increases complication rate ${ }^{11}$. In this study, frequent omission was observed in recording passage of stool/urine; correct using of sign, lack off intervention record on the chart like operation, antibiotic, blood transfusion etc.

Compared to the admission and discharge record, quite satisfactory performance rate was observed in complete set of forms $(81.7 \%)$. Performance score $(78.2 \%)$ was observed in patient consent for treatment and release authorization forms. The performance score observed in component in quality indicator was complete set of forms (72.2\%) followed by treatment chart 60.8 percent. Most physicians report having engaged in questionable hospital chart documentation. This practice is more common among physicians who are younger, working with house staff ${ }^{12}$. As physicians the majority of discharge summaries even though they usually receive little or no trains in the creation of discharge summaries during their medical school. It is possible that differences in formal education or informal discharge summary training during residency accounts for the variation observed here. 


\section{CONCLUSION}

The structure which includes the organizational support for the system was not impressive. There was inadequate allocation of staff, very congested physical space, poor filing and computer entry system. Technology and materials were used substandard. Substantial improvement is need in the future regarding the methods of documentation, retrieving, filing/ coding. In the process of taking consent the indication of the treatment/operation, minor/major side effects and complications should be discussed before taking signature, however the process of consent could not be assessed in this study. Provision of a room with adequate space should be available near to the ticket counter which provides the advantage to abstract follow up record immediately. The hospital record file for the follow up patient should be reached beforehand in outpatient department during follow up visits. A guideline for the documentation should be produced and implemented to enhance quality documentation.

In only a minority of the quality indicators specified rigorous practice of documentation in Chitwan School of Medical Sciences. Overall results demonstrated that the admission record, legibility of discharge summaries and coherent and consistency of documentation were poorly adhere to most of the standard, however given information play a pivotal communication role in case management/transitions. Even a small frequency of discharge condition information is a concern and may influence patient safety. Standardization itself affects practice patterns substantially. A modification of the documentation system component standards might be instrument in changing $\mathrm{CMC}$ discharge summary documentation practice.

\section{Limitation of the study}

This study did not look for the implication of poor documentation practice, Complication, re-admission and death as well as implication in cost. The primary limitation of this study relate to its preliminary nature and overall generality. Given that this result are based on a subset of our total sample, including only a very small number of cases. The component definition presented here was set as local standard might not be suitable for the measurement in other institution.

\section{ACKNOWLEDGEMENTS}

I would like to thank Dr. L. B. Sedai and Dr. A. Shrestha for their valuable support to complete this study. Thanks also goes to Dr. Lalan Saha, Dr. Dikchhaya, Dr. Harisankar, Ms. Sita Nepal and staff working in medical record section.

\section{REFERENCES}

1. Brennan $T A$, Localio $A R$, Leape $L L$, et al. Identification of adverse events occurring during hospitalization. A cross-sectional study of litigation, quality assurance, and medical records at two teaching hospitals. Ann Intern Med 1990;112:221-6.

2. Wilson RM, Runciman WB, Gibberd RW. The Quality in Australian
Health Care Study. Med J Aust1995;163:458-71.

3. Brennan TA, Leape LL, Laird NM, et al. Incidence of adverse events and negligence in hospitalized patients. Results of the Harvard Medical Practice Study. Engl J Med 1991;324:370-6.

4. Soop M, Fryksmark U, Köster M, et al. The incidence of adverse events in Swedish hospitals: a retrospective medical record review study. Int J Qual Health Care 2009;4:285-91.

5. Amarasingham $R$, Plantinga $L$, Diener-West $M$. Clinical information technologies and inpatient outcomes: A multiple hospital study. Arch Intern Med 2009;169:108-14.

6. Gandara E, Moniz T, Ungar J, Lee J, Chan-Macrae M, O'Malley T, Schnipper JL. Communication and information deficits in patients discharged to rehabilitation facilities: an evaluation of five acute care hospitals Hosp Med. 2009 Oct;4(8):E28-33.

7. Louden K. Creating a better discharge summary is standardization the answer? ACP Hospitalist, American College of Physicians Mar 2009.

8. Zegers $M$, Bruijne MC, Spreeuwenberg $P$, Wagner $C$, Groenewegon P, Van der wal G. Quality of patient record keeping: an indicator of the quality of care. BMC Health Serv hRes 2007; 7:27.

9. Maslove DM, Biter RE, Griesman J, Arnott C, Mousad O, Chow $\mathrm{CM}$, Bell CM. Electronic versus dictated hospital discharge summaries: a randomize controlled trial. Journal of general internal medicine 2010;24(9)995-1001.

10. Kazmi S MB. Quality of Electronic Discharge Summaries at Newham University Hospital: An Audit. BJMP 2008;1(1)30-32.

11. Carlsson E, Ehnfors M, Eldh AC, Ehenberg A. Accuracy and continuity in discharge information for patient with eating difficulty after stroke, J Clin Nurs 2011 may 12 1365270AWalraven CV, Seth R, Austin CP, Laupacis A. Effect of discharge summary availability during post-discharge visit on hospital readmission. J Gen Intern Med. 2002;17 (3):186-192.

12. Sharma R, Kostis W J, Wilson AC, Cosgrove NM, Hassett AL, Moreyra AE, Delnevo CD, Kostis JB. Questionable Hospital Chart Documentation Practices by Physicians Journal of General Internal Medicine 2008;23(11):1865-1870. 